\section{Leaf Scorch Epidemics Reduce Vegetative Growth and Fruit Yield of 'Kent' Strawberry}

\author{
J.M. Mutisya, J.A. Sullivan, ${ }^{1}$ and S. Couling \\ Department of Plant Agriculture, Horticultural Science Division
}

\section{J.C. Sutton and J. Zheng \\ Department of Environmental Biology, University of Guelph, Guelph, Ontario N1G 2W1 Canada}

Additional index words. foliar disease, Fragaria $\times$ ananassa, growth analysis, Marssonina fragariae

\begin{abstract}
The relationship between severity of leaf scorch epidemics, caused by Diplocarpon earlianum, and components of vegetative growth and fruit yield was examined in 'Kent' strawberry (Fragaria $\times$ ananassa Duch.). Plants were treated in July with six densities of initial inoculum of the pathogen, and severity of leaf scorch was assessed at 2-week intervals from late July to late October. After an analysis of vegetative growth in late October, plants were overwintered in the field or grown in a greenhouse, and later assessed for yield components. Relationships between area under the disease progress curve (AUDPC) and plant growth and yield components were examined by regression analysis. Significant negative linear relationships were found between AUDPC values and number of green leaves, leaf area, leaf dry weight, crown number, crown dry mass, and root dry weight. Significant negative relationships were also found between AUDPC values and number of flowers and inflorescences, and total and marketable berries in the subsequent season, in plants maintained in the field or in the greenhouse. Mean berry weight was not significantly affected. Reduction in the number of crowns in plants affected by leaf scorch was a major factor limiting the yield of diseased plants. In an analysis of regrowth at seven weeks after fruit harvest, a significant negative linear relationships was found between AUDPC values and each growth component except crown dry weight. Collectively, the data provide a rationale to optimize timing of treatments, such as chemical fungicides or microbial agents, to control leaf scorch in August, September and October and thereby promote berry yield in the subsequent season.
\end{abstract}

Leaf scorch of strawberry (Fragaria $\times$ ananassa Duch.) caused by Diplocarpon earlianum (Ellis \& Everh.) F.A. Wolf (anamorph Marssonina fragariae (Lib.) Kleb.) is a destructive disease that is coextensive with strawberry production throughout the world (Plakidas, 1964). Symptoms of the disease develop on the leaves, peduncles, pedicels, calcyces, petals, and fruits (Maas,1998; Wolf, 1926). As epidemics progress the leaves often develop a scorched appearance and the plants may be stunted or killed, especially in cultivars that are moderately or highly susceptible. In Ontario, Canada, and in other regions of North America, leaf scorch epidemics in Junebearing cultivars develop chiefly in late summer and fall (Converse et al., 1981; Scott et al., 1969; Zheng and Sutton, 1994). When epidemics are severe, potential for winter damage is increased and yield and quality of the fruit in the following year can be markedly reduced (Plakidas, 1964; Wolf, 1926). This implies a link between disease severity and yield potential established during flower bud initiation. Quantitative information on leaf scorch epidemics in relation to vegetative growth and fruit yield has not been reported, but is needed for improving measures to control scorch and optimizing yields.

In studies of healthy strawberry plants, leaf

Received for publication 1 Oct. 2003. Accepted for publication 15 Jan. 2004.

${ }^{1}$ Corresponding author; e-mail asulliva@uoguelph.ca. area, total leaf dry weight, crown dry weight, and several other components of vegetable growth in the fall correlated strongly and positively with yield in the following crop season (Strik and Proctor, 1988a). Chercuitte et al. (1991) concluded that the number of leaves and green leaf area of strawberry in the fall should be maximized in order to optimize yield potential in the following year. In north-eastern North America, early fall is a critical period of flower bud initiation and of the establishment of yield potential for the next crop season. From these considerations it can be conjectured that destruction of foliage by $D$. earlianum in late summer and fall would seriously affect yield in the subsequent crop season.

The objective of this study is to determine and quantify relationships of leaf scorch epidemics to vegetative growth in the fall and to vegetative growth and yield in the following spring. The highly susceptible cultivar 'Kent' was used for the investigations.

\section{Materials and Methods}

Field plots. Runner plants of 'Kent' strawberry from a commercial propagator were planted in small plots arranged in five blocks and maintained in a runner-less system similar to waiting-beds (Chercuitte et al., 1991) at the Research Station, Cambridge, Ontario, on 17 May 1991. Each plot comprised five rows of ten plants, which were spaced $0.15 \mathrm{~m}$ apart within rows and between rows in a grid pattern. Blocks, and plots within blocks, were separated by strips of cultivated soil $1 \mathrm{~m}$ wide of which the middle portion 0.3 m wide was seeded with barley to serve as a barrier among treatments. The plants were watered after transplanting and subsequently as needed to maintain adequate soil moisture. Fertilizer $(13 \mathrm{~N}-0 \mathrm{P}-44 \mathrm{~K})$ was broadcast on the plots at $25 \mathrm{~kg} \cdot \mathrm{ha}^{-1} 1 \mathrm{~d}$ before planting. A straw mulch was applied among the plants to conserve soil moisture and suppress weeds. Emerging weeds were controlled by hand cultivation. Flower inflorescences and runners were removed by hand in accordance with protocol for a runnerless system (Chercuitte et al., 1991).

Inoculum and inoculation treatments. Inoculum of $D$. earlianum was produced on bean pod-sucrose-malt-extract agar medium (Dhanvantari, 1967) in petri dishes at 20 to $21{ }^{\circ} \mathrm{C}$. One milliliter of spore suspension $(2 \times$ $10^{3}$ conidia $/ \mathrm{mL}$ ) was spread on the medium in each dish. After $30 \mathrm{~d}$, conidia of the pathogen were recovered by flooding the cultures with sterile distilled water plus surfactant $(0.1 \mathrm{~mL}$ Triton $X-100 / 100 \mathrm{~mL}$ ), rubbing the sporulating colonies with a bent glass rod, and filtering the spore suspensions through four layers of sterilized cheese cloth. Conidial densities were estimated with the aid of a haemacytometer and diluted with distilled water to about $2.5 \times 10^{3}$, $5.0 \times 10^{3}, 1 \times 10^{4}, 5 \times 10^{4}$, and $1 \times 10^{5}$ conidia per $\mathrm{mL}$ for inoculations.

The inocula were used to initiate leaf scorch epidemics of differing intensity in the strawberry field plots. There were six treatments, each with four replicate plots, arranged as a randomized complete block. In the control treatment where minimal scorch development was initiated by inoculum from natural sources or minor interplot interference, plants were treated with water plus surfactant on 14 July, and with Captan (50 WP, $6.75 \mathrm{~kg} \cdot \mathrm{ha}^{-1}$ ) at weekly intervals beginning on 28 July 1991 until the end of the season. For the remaining five treatments the various inoculum densities were applied on 14 and 28 July 1991, except for the lowest density, which was applied on 14 July only. Inoculum was applied to point of runoff using a hand-held sprayer.

Disease estimations. Symptoms of leaf scorch were assessed at 2-week intervals from 28 July to 28 Oct. At each time of assessment

Table 1. A modified Horsfall-Barratt grading system used for converting rated grade scores to estimated percent diseased leaf area on strawberry leaves. Based on Redman, King and Brown of Eli Lilly and Co. (Elanco Division).

\begin{tabular}{lcc}
\hline Grade & $\begin{array}{c}\text { Diseased } \\
\text { leaf } \\
\text { area } \\
(\%)\end{array}$ & $\begin{array}{c}\text { Grade } \\
\text { formula } \\
(\%)\end{array}$ \\
\hline 1 & 0 & 1.17 \\
2 & $0-0.3$ & 1.40 \\
3 & $0.3-0.6$ & 1.65 \\
4 & $0.6-1.5$ & 2.30 \\
5 & $1.5-3.0$ & 3.09 \\
6 & $3.0-6.0$ & 4.68 \\
7 & $6.0-12.5$ & 9.62 \\
8 & $12.5-25$ & 19.00 \\
9 & $25-50$ & 37.50 \\
10 & $50-100$ & 74.75 \\
\hline
\end{tabular}


the disease was estimated on two lower, middle, and upper leaves of each of five randomly selected plants in each plot, for a total of 30 leaves per plot. The percent leaf area discolored was estimated for each leaf with the aid of the disease severity scale in Table 1 . Diseased leaf area ratings were converted to percent diseased leaf area values using the grade formula system modified from Horsfall and Barratt (1945) by Redman, King and Brown (Table 1). The grade formula values of the 30 leaves per plot were averaged and used to establish disease progress curves for the six treatments.

Disease severity in the six treatments was compared by calculating values for area under the disease progress curve (AUDPC) using the following equation (Shaner and Finney, 1977): $\operatorname{AUDPC}=\sum \mathrm{n}_{\mathrm{i}=1}\left(\left(\mathrm{Y}_{\mathrm{i}+1}+\mathrm{Y}_{\mathrm{j}}\right) / 2\right)\left(\mathrm{X}_{\mathrm{i}+1}-\mathrm{X}_{\mathrm{i}}\right)$, where $\mathrm{Yi}=$ the percent of diseased leaf area at the ith day of assessment, $\mathrm{Xi}=$ time of the ith assessment in days from that of the first assessment, and $n=$ total number of times of disease assessment. AUDPC values were estimated for the entire epidemics (28 July to 28 Oct.) and for successive portions of the epidemics (i.e., 28 July to 12 Aug., 13 Aug. to 10 Sept., 11 Sept. to 10 Oct., and 11 to 28 Oct.).

Measurement of vegetative growth. Components of vegetative growth of plants in the waiting beds were estimated on 29 Oct., immediately after the final disease assessment. Each estimate was an average for five plants that were dug at random in each plot. Fresh weight and dry weight of the crowns, roots, and green leaves, and the number and area of the green leaves were measured per plant. Dry weights were recorded after samples were dried at 85 ${ }^{\circ} \mathrm{C}$ for $5 \mathrm{~d}$. Green leaf area was measured using an area meter (LI-3000; Lambda Instruments Corp., Lincoln, Neb.) fitted with a transparent belt accessory (LI-3050A).

Yield studies. Yields were estimated using plants that overwintered in one half of each field plot and using plants that were dug from the other half of each plot and later grown in greenhouse cropping beds. All plants had thus developed through one waiting-bed phase, which was similar to a runnerless culture system in which plants remain vegetative during the first season.

The plants that were left in the field plots were covered with straw from November until May. Fertilizer(16N-8P-8K) was applied to the plots in May at a rate of $25 \mathrm{~kg} \cdot \mathrm{ha}^{-1}$. Sprinklers were used to irrigate the plot area to field capacity on 15 May and to maintain soil moisture at other times in the growing season. Number of leaves and inflorescences per plant and petiole length were measured on a random sample of five plants per plot. All ripe fruit in the plots were picked by hand, counted and weighed at least twice weekly. Average fruit weight was calculated for each harvest as total fruit weight $\div$ total fruit number.

For cropping beds in aresearch greenhouse 24 plants were dug from each half plot on 15 Nov. The plants were washed to remove soil, dipped in Captan (50 WP) $(0.2 \% \mathrm{w} / \mathrm{v})$, stored in plastic bags at -1 to $-2{ }^{\circ} \mathrm{C}$ (Chercuitte et al., 1991) until 13 Jan., and allowed to acclimate at $15^{\circ} \mathrm{C}$ for $1 \mathrm{~d}$ before planting. Three plants from each replicate plot of each treatment were planted in each of four 20-L pots containing Promix (Plant Products Ltd., Brampton, Ont.) for a total of 12 plants which comprised a plot for the yield trial. The experiment was designed as a randomized complete block with four replications and six treatments, as used in the waiting beds during the previous season. After planting, soil in the pots was watered initially to saturation, and later trickle-irrigated with about $1 \mathrm{~L}$ of water per pot each day. Fertilizer $(15 \mathrm{~N}-15 \mathrm{P}-15 \mathrm{~K})$ was applied every two days at a rate $1.8 \mathrm{~g} \cdot \mathrm{L}^{-1}$. Air temperature in the greenhouse was $23 / 20^{\circ} \mathrm{C}$ day/night and the relative humidity was $40 \%$ to $45 \%$. Insect pests were controlled with natural predators as needed. During flowering petiole length was estimated based on five leaves per plant and inflorescences and flowers were counted on each plant. A camelhair brush was used to enhance pollination. Fruit data were collected twice a week from 13 Mar. until 19 Apr. To simulate crop renovation, all leaves were removed after the final fruit harvest, and two weeks later, fertilizer (20N-20P-20K) was applied at a rate of $2 \mathrm{~g} \cdot \mathrm{L}^{-1}$. After the plants had regrown for about 7 weeks, a growth analysis was conducted using the procedure described in Chercuitte et al. (1991).

The number and fresh weight of total fruit and of marketable fruit per plant, and the mean weight per fruit of total and marketable fruits were measured. In both trials, harvested fruit were classed as marketable ( $>2 \mathrm{~cm}$ in diameter and of regular shape) and unmarketable (any irregularly shaped or damaged fruits and all fruit $<2 \mathrm{~cm}$ in diameter). The percent of flowers that aborted was calculated from: (total flowers - total fruit/total flowers) $\times 100$.

Dataanalysis. Data were subjected to analysis of variance(ANOVA) using the GLM program of SAS (SAS, Cary, N.C.). Regression analysis was used to examine the relationship between severity of foliage disease (AUDPC, the independent variable) and change in vegetative characters and yield components (the dependent variables) during August to October in the field plots.

\section{Results}

Scorch symptoms on the foliage increased in severity in all treatments in the waiting bed plots during August to October. Increased density of initial inoculum from 0 to $10^{5}$ conidia/mL resulted in corresponding increases in severity of leaf scorch epidemics in the plots, which are reported as AUDPC values (Table 2). The AUDPC values increased from 8.6 in plots treated with water and surfactant only to 46.5 in those treated with the highest inoculum density.

In general, all of the vegetative components measured at the end of October declined with increases in severity of the scorch epidemics during August to October (Table 2). A negative linear relationship was observed between AUDPC and green leaf number, leaf area, leaf dry weight, crown number, crown dry weight and root dry weight. Average green leaf area and number of crowns in the most severely diseased plants were reduced by $58 \%$ (605.3 $\mathrm{cm}^{2} /$ plant) and $25 \%$ (2.4/plant), respectively, compared to those of the control plants. Similarly, the most severe leaf scorch reduced leaf dry weight, leaf area and green leaf number by $61 \%, 58 \%$, and $50 \%$, respectively, compared to the controls. Severely diseased plants were small as indicated by the low dry weights, but those remaining in the field plot survived the winter under the straw mulch.

Flowering of plants left in the field plots overwinter began about $30 \mathrm{~d}$ after the straw was removed. Significant negative relationships were found between severity of scorch epidemics during the previous August to October period and numbers of flowers and inflorescences, total and marketable berries per plant, and total and marketable berry yields per plant in the subsequent year (Table 3). The most severe epidemic decreased total berry yields by $27 \%$. No significant relationship was found between scorch severity and average berry weight.

Flowering of plants transferred to the greenhouse cropping beds also began about 30 days after transplanting. Significant negative relationships were found between severity of the scorch epidemics during August to October and the same yield components found in the overwintered plants (Tables 3 and 4). In the trials in the field and greenhouse, decreases in total and marketable yields with increase in AUDPC values were due to a decrease in fruit number since total and marketable mean fruit weights were relatively constant among treatments in each trial. Total

Table 2. Effects of the severity of leaf scorch epidemics on vegetative growth of 'Kent' strawberry.

\begin{tabular}{|c|c|c|c|c|c|c|}
\hline \multirow{2}{*}{$\begin{array}{l}\text { Scorch } \\
\text { severity } \\
\text { AUDPC }^{z} \\
\text { values }\end{array}$} & \multicolumn{3}{|c|}{ Leaf } & \multicolumn{2}{|c|}{ Crown } & \multirow{2}{*}{$\begin{array}{c}\text { Root } \\
\text { Dry wt } \\
\text { (g/plant) }\end{array}$} \\
\hline & $\begin{array}{l}\text { No./ } \\
\text { plant }\end{array}$ & $\begin{array}{c}\text { Area } \\
\left(\mathrm{cm}^{2} / \text { plant }\right)\end{array}$ & $\begin{array}{c}\text { Dry wt } \\
\text { (g/plant) }\end{array}$ & $\begin{array}{l}\text { No./ } \\
\text { plant }\end{array}$ & $\begin{array}{c}\text { Dry wt } \\
\text { (g/plant) }\end{array}$ & \\
\hline 8.6 & 21.7 & 1430.2 & 20.6 & 3.2 & 8.2 & 9.7 \\
\hline 22.5 & 18.8 & 1204.3 & 16.7 & 3.4 & 7.6 & 9.2 \\
\hline 31.3 & 15.7 & 950.6 & 13.7 & 2.7 & 7.8 & 7.4 \\
\hline 36.8 & 13.2 & 749.4 & 9.8 & 2.6 & 8.1 & 6.9 \\
\hline 40.4 & 10.7 & 631.5 & 8.7 & 2.7 & 6.1 & 6.4 \\
\hline 46.5 & 10.8 & 605.3 & 8.1 & 2.4 & 5.7 & 5.6 \\
\hline \multicolumn{7}{|l|}{ Significance } \\
\hline Linear ( $P$ values) & 0.0001 & 0.0001 & 0.0001 & 0.0039 & 0.0006 & 0.0001 \\
\hline Quadratic ( $P$ values) & 0.7926 & 0.9550 & 0.8770 & 0.6473 & 0.6604 & 0.5830 \\
\hline$b_{1}$ linear & -0.28 & -23.07 & -0.38 & -0.01 & -0.10 & -0.06 \\
\hline$b_{2}$ quadratic & NS & NS & NS & NS & NS & NS \\
\hline$R^{2}$ & 0.84 & 0.85 & 0.88 & 0.55 & 0.57 & 0.62 \\
\hline
\end{tabular}


fruitnumber of the most severe treatmentdeclined $28 \%$ and $41 \%$ in the overwintered and greenhouse trials, respectively.

The effect of leaf scorch epidemics on vegetative regrowth 7 weeks after fruit harvest was investigated after the greenhouse yield trial was completed. All vegetative components demonstrated a significant negative linear relationship with AUDPC the previous season (Table 5). Leaf area per plant and crown and root dry weights were reduced by $27 \%, 33 \%$, and $54 \%$, respectively, in plants of the most severe scorch epidemic compared to those of the control.

\section{Discussion}

The observations indicated that leaf scorch markedly affected vegetative growth and yield potential of 'Kent' strawberry, a cultivar that is widely grown in eastern Canada and the northeastern United States. Increases in severity of the scorch epidemics produced by increased density of D. earlianum inoculum progressively reduced size and vigor of the plants at the end of the season. Green leaf areas, crown numbers, and vegetative dry weights were substantially lower in the inoculated plants compared to the noninoculated controls. Scorch reduced number of crowns, number of inflorescences per crown, and mean fruit weight, and thus total and marketable yields the following season.

The data indicated that reduction in green leaf area, a principal effect of scorch epidemics, contributed to the observed declines in crown number, crown dry weight, and root dry weight. Earlier reports suggested that loss of photosynthetic capacity reduced growth and productivity in plants affected by scorch, but did not provide quantitative evidence (Maas, 1998; Wolf, 1926).

Kerkoffetal.(1988a) found that strawberry plants

Table 3. Relationships of leaf scorch epidemics during July to October to yield and yield components in the subsequent year in 'Kent' strawberry plants that were overwintered in the field.

\begin{tabular}{|c|c|c|c|c|c|c|c|c|c|}
\hline \multirow{2}{*}{$\begin{array}{l}\text { Scorch } \\
\text { severity } \\
\text { AUDPC } \\
\text { values }\end{array}$} & \multicolumn{3}{|c|}{ Total } & \multicolumn{3}{|c|}{ Marketable } & \multirow[b]{2}{*}{$\begin{array}{l}\text { Flowers/ } \\
\text { plant } \\
\text { (no.) }\end{array}$} & \multirow[b]{2}{*}{$\begin{array}{l}\text { Inflorescences/ } \\
\text { plant } \\
\text { (no.) }\end{array}$} & \multirow[b]{2}{*}{$\begin{array}{c}\text { Aborted } \\
\text { flowers } \\
(\%)\end{array}$} \\
\hline & $\begin{array}{l}\text { Yield } \\
\text { (g/plant) }\end{array}$ & $\begin{array}{c}\text { Berries/ } \\
\text { plant } \\
\text { (no.) }\end{array}$ & $\begin{array}{c}\text { Avg } \\
\text { berry } \\
\text { wt }(g)\end{array}$ & $\begin{array}{l}\text { Yield } \\
\text { (g/plant) }\end{array}$ & $\begin{array}{c}\text { Berries/ } \\
\text { plant } \\
\text { (no.) }\end{array}$ & $\begin{array}{l}\text { Avg } \\
\text { berry } \\
\text { wt }(g)\end{array}$ & & & \\
\hline 31.3 & 308.5 & 46.3 & 6.7 & 291.0 & 36.1 & 8.1 & 56.4 & 5.5 & 19.0 \\
\hline 36.8 & 278.7 & 44.6 & 6.3 & 269.8 & 34.7 & 7.7 & 53.5 & 5.0 & 15.1 \\
\hline 40.4 & 250.5 & 41.8 & 6.0 & 235.6 & 31.4 & 7.5 & 49.4 & 4.8 & 14.8 \\
\hline Linear ( $P$ values $)$ & 0.0001 & 0.0001 & 0.7077 & 0.0001 & 0.0001 & 0.5730 & 0.0001 & 0.0001 & 0.0221 \\
\hline Quadratic ( $P$ values) & 0.0134 & 0.0102 & 0.3756 & 0.0146 & 0.0125 & 0.5001 & 0.0327 & 0.9006 & 0.4807 \\
\hline $\mathrm{b}_{1}$, linear & 0.18 & 2.27 & NS & 0.09 & 2.23 & NS & 0.20 & -0.08 & 0.07 \\
\hline $\mathrm{b}_{2}$, quadratic & -0.01 & -0.08 & NS & -0.01 & -0.08 & NS & -0.01 & NS & NS \\
\hline$R^{2}$ & 0.79 & 0.79 & 0.18 & 0.87 & 0.75 & 0.13 & 0.82 & 0.81 & 0.51 \\
\hline
\end{tabular}

${ }^{2}$ AUDPC $=$ area under disease progress curve values calculated for the period 28 July to 28 Oct. 1991.

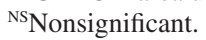

Table 4. Relationships of leaf scorch epidemics during July to October to yield and yield components of greenhouse grown 'Kent' strawberry.

\begin{tabular}{|c|c|c|c|c|c|c|c|c|c|}
\hline \multirow{2}{*}{$\begin{array}{l}\text { Scorch } \\
\text { severity } \\
\text { AUDPC } \\
\text { values }\end{array}$} & \multicolumn{3}{|c|}{ Total } & \multicolumn{3}{|c|}{ Marketable } & \multirow[b]{2}{*}{$\begin{array}{c}\text { Flowers/ } \\
\text { plant } \\
\text { (no.) }\end{array}$} & \multirow[b]{2}{*}{$\begin{array}{l}\text { Inflorescences/ } \\
\text { plant } \\
\text { (no.) }\end{array}$} & \multirow[b]{2}{*}{$\begin{array}{l}\text { Aborted } \\
\text { flowers } \\
(\%)\end{array}$} \\
\hline & $\begin{array}{c}\text { Yield } \\
\text { (g/plant) }\end{array}$ & $\begin{array}{c}\text { Berries/ } \\
\text { plant } \\
\text { (no.) }\end{array}$ & $\begin{array}{c}\text { Avg } \\
\text { berry } \\
\text { wt }(g)\end{array}$ & $\begin{array}{c}\text { Yield } \\
\text { (g/plant) }\end{array}$ & $\begin{array}{c}\text { Berries/ } \\
\text { plant } \\
\text { (no.) }\end{array}$ & $\begin{array}{c}\text { Avg } \\
\text { berry } \\
\text { wt (g) }\end{array}$ & & & \\
\hline 22.5 & 133.5 & 32.6 & 4.1 & 109.6 & 21.2 & 5.3 & 38.8 & 3.6 & 16.1 \\
\hline 31.3 & 121.3 & 30.5 & 4.0 & 100.3 & 18.3 & 5.6 & 35.4 & 3.0 & 14.5 \\
\hline 36.8 & 110.4 & 27.8 & 4.0 & 88.8 & 15.3 & 5.6 & 35.2 & 3.0 & 21.4 \\
\hline 40.4 & 90.8 & 20.9 & 4.4 & 78.3 & 13.6 & 5.8 & 25.4 & 3.4 & 17.4 \\
\hline Linear ( $P$ values) & 0.0001 & 0.0001 & 0.3007 & 0.0001 & 0.0001 & 0.0625 & 0.0001 & 0.0001 & 0.6464 \\
\hline Quadratic ( $P$ values) & 0.0252 & 0.0242 & 0.8621 & 0.1450 & 0.0653 & 0.7797 & 0.0183 & 0.8002 & 0.8410 \\
\hline $\mathrm{b}_{1}$, linear & 0.44 & 1.68 & NS & 0.11 & 1.02 & NS & 0.48 & -0.03 & NS \\
\hline$b_{2}$, quadratic & -0.01 & -0.08 & NS & -0.01 & -0.08 & NS & -0.01 & NS & NS \\
\hline$R^{2}$ & 0.69 & 0.74 & 0.19 & 0.72 & 0.72 & 0.27 & 0.69 & 0.73 & 0.20 \\
\hline
\end{tabular}

${ }^{2}$ AUDPC $=$ area under disease progress curve values calculated for the period 28 July to 28 Oct. 1991.

${ }^{\mathrm{NS}}$ Nonsignificant.

Table 5. Vegetative regrowth seven weeks after harvest of greenhouse grown 'Kent' strawberry exposed to leaf scorch epidemics the previous season.

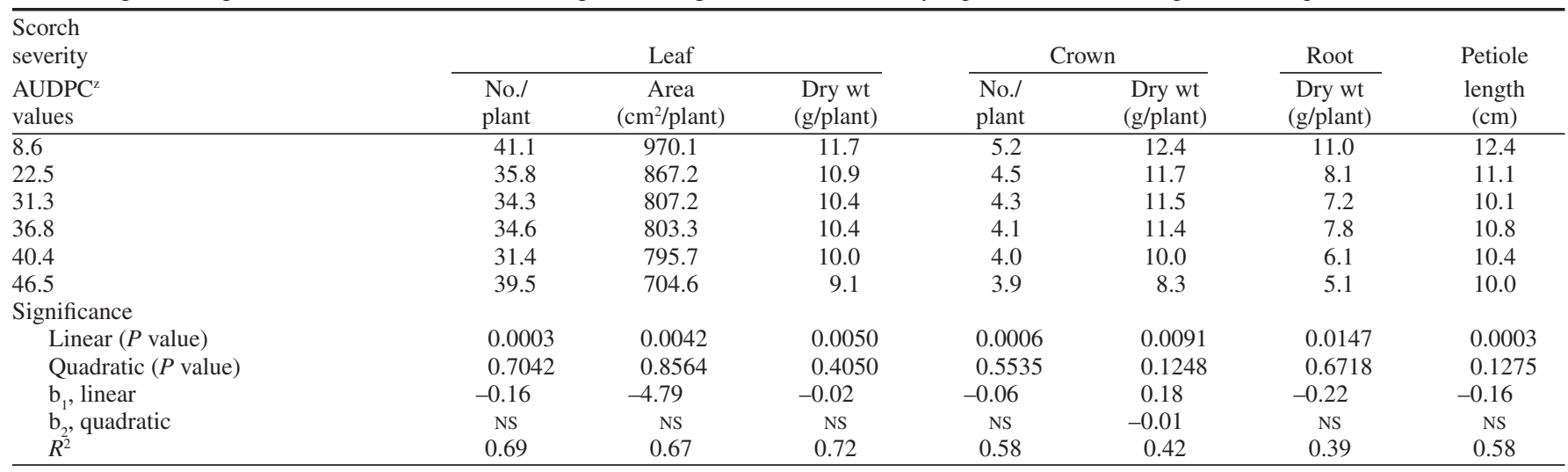

${ }^{2}$ AUDPC $=$ area under disease progress curve values calculated for the period 28 July to 28 Oct. 1991.

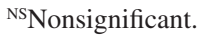


compensated for reduced leaf area by increased net photosynthesis within a few days aftermanual defoliation. Net photosynthetic rate of remaining leaves, expressed on a per leaf basis, increased to a maximum when $66 \%$ of the leaf area was removed, and partially compensated for reduced leaf area in terms of dry matter production. In the present study the proportion of leaf area affected by scorch apparently exceeded ability of the unaffected portions of leaves to compensate photosynthetically.

Findings that increased severity of scorch epidemics reduced yield potential in the subsequent season can be explained in terms of effects of the disease on yield components at the time of the epidemics. Inflorescence number, flower number, and berry number are determined in June-bearing cultivars during flower bud initiation late in the preceding season (Strik, 1985), and can be affected by environmental factors at that time (Webb et al., 1974). In the present study, flower bud initiation coincided with periods of rapid increase in scorch severity. Several vegetative components that were reduced by scorch, including leaf area, leaf dry weight, and crown dry weight, are known to correlate positively with fruit yield in the following season in strawberry genotypes differing in yield potential (Strik and Proctor, 1988a). Several other authors also reported relationships between loss of leaf area in the fall and yield reductions in the subsequent season (Guttridge and Mason, 1966; Kerkhoff et al., 1988b; Moore, 1968). A reduction in dry matter accumulation in scorch-affected plants probably limited flower bud initiation and branch crown formation, and thus economic yield potential. In northeastern North America, flower bud initiation begins during mid to late August if temperatures are favourable (Guttridge, 1985). Any factors negatively impacting the plant during this period will adversely affect flower bud initiation and yield potential. For example, defoliation during early September was more related to a decrease in berry number (and hence yield) the following season than was defoliation in August (Kerkhoff et al., 1988b).

Crown number is a yield component of strawberry that is very susceptible to environmental stress factors. In competition studies, Hesketh et al. (1990) demonstrated that crown number decreased in response to stress associated with increased plant density. Crown number and yield have been strongly and positively correlated in several cultivars (Hancocketal., 1983). Accordingly, in the present study, the observed effect of leaf scorch on crown number was probably the prime cause for yield reduction. In studies by Kerkhoff et al (1988b), manual defoliation caused a linear reduction in total berry number such that complete defoliation reduced berry number by $27 \%$ a value similar to the $28 \%$ reduction in berry number that we found for plants of the most severe scorch treatment in the overwintered field trial. It is possible that partial defoliation may not reduce sunlit leaf area when leaf area index is high and thus may not reduce yield per se or remaining leaves may compensate by increasing carbon exchange rate. However, the effect of low levels of defoliation and disease may not be comparable because partial defolia- tion may only decrease the amount of shading of the lower leaves (Olsen et al., 1985). In contrast, when leaf scorch attacks upper leaves it may actually reduce functional leaf area, having a greater impact on growth and development. The lowest and second lowest levels of leaf scorch decreased yield by $7 \%$ and $13 \%$ respectively, in the overwintered field trial.

Defoliation also affects the rate and duration of flower bud initiation (Mason, 1966), characters that were not measured in the present study. However, no differences were found among the levels of scorch severity in number of inflorescences per crown or fruit per crown, which supports the view that scorch chiefly affected the number of crowns per plant.

Even though scorch reduced plant vigour, plants of all treatments survived the winter protected by the straw mulch. However, growth and yields in subsequent seasons may be further reduced due to a reduction in the amount of stored carbohydrates (Galleta and Hilmerick, 1990). In the present study, the reduction in regrowth after renovation was the consequence of the carryover effect of reduced vigour observed in plants with high disease levels. Vegetative vigour is important for flower bud initiation (Chercuitte et al., 1991; Webb et al., 1974) and storage of reserve carbohydrates (Galletta and Hilmerick, 1990) that acts as a source of energy for initial leaf expansion and flower development during early spring (Janick and Sherman, 1960). Should disease be severe in successive seasons resulting in reduced carbohydrate accumulation, the plants may eventually lack sufficient vigour for winter survival or effective productivity.

Although leaf scorch decreased total fruit number and fruit weight per plant in the yield trials, average berry weight was unaffected. Strik and Proctor (1988b) noted that berry size within a genotype was related to total number of achenes per berry. Generally, berry size is determined by influence of developed achene number, achene size and achene activity (Moore et al., 1970).

In conclusion, leaf scorch significantly impacted vegetative growth and yield potential of 'Kent' strawberry. Yield was most limited chiefly by the number of crowns per plant, which decreased as scorch severity increased while numbers of inflorescences per crown and fruits per inflorescence were similar among scorch severity levels. Since the period from late July to mid-September is the most critical for branch crown development and yield establishment, greater disease severity at this time would lead to increased yield loss the following season. Suppression of leaf scorch early in the season, so as to maintain a healthy leaf area during crowninitiation and development, could partially compensate for decreased leaf area later in the season and reduce the impact of scorch epidemics on crown number when disease levels are high. The data provide a rationale to optimize timing of treatments, such as chemical fungicides or microbial agents, to control leaf scorch at critical periods so as to promote crown number and thus fruit yields. The relationship between crown number and fruit number per crown varies greatly among cultivars (Hancock et al., 1983). The impact of leaf scorch on the vegetative and reproductive growth of other cultivars may also be different than those noted with 'Kent', a highly susceptible cultivar.

\section{Literature Cited}

Chercuitte, L., J.A. Sullivan, Y.D. Desjardins, and R. Bedard. 1991. Yield potential and vegetative growth of summer-planted strawberry. J. Amer. Soc. Hort. Sci. 116:930-936.

Converse, R.H., W.C. Denison, and F.J. Lawrence. 1981. Reaction of some Pacific Coast strawberry cultivars to leaf scorch. Plant. Dis. 65:254-255.

Dhavantari, B.N. 1967. The leaf scorch disease of strawberry (Diplocarpon earlianum) and the nature of resistance to it. Can. J. Bot. 45:1525-1543.

Galletta, G.J. and D.G. Hilmerick. 1990 (eds.). Small fruit crop management, p. 83-156. Prentice-Hall, Englewood Cliff, N.J.

Guttridge, C.G. 1985. Fragaria $\times$ ananassa. CRC handbook of flowering, p. 16-29. vol. 3. CRC Press, Boca Raton, Fla.

Guttridge, C.G. and M.T. Mason. 1966. Effects of post-harvest defoliation of strawberry plant on truss initiation, crown branching and yield. Hort. Res. 6:22-32.

Hancock, J.F., J.H. Siefker, and N.L. Schulte. 1983. Cultivar variation in yield components of strawberries. HortScience 18:312-313.

Hesketh, J.L., G.W. Eaton, and T.E. Baumann. 1990. Strawberry plant spacing on raised beds. Fruit Var. J. 44:12-17.

Horsfall, J.G. and R.W. Barratt. 1945. An improved grading system for measuring plant diseases. Phytopathology 35:665.

Janick, J. and W.B. Sherman. 1966. Greenhouse evaluation of fruit size and maturity in strawberry. Proc. Amer. Soc. Hort. Sci. 89:303-308.

Kerkhoff, K.L., J.M. Williams, and J.A. Barden. 1988a. Net photosynthesis rate and growth of strawberry after partial defoliation. HortScience 23:1086-1088.

Kerkhoff, K.L., J.M. Williams, and J.A. Barden. 1988b. Effects of defoliation on growth and yield of 'Redchief' strawberries. Adv. Strawberry Prod. 7:26-28.

Maas, J.L. 1998. Compendium of strawberry diseases, p. 19-20. Amer. Phytopathol. Soc.

Mason, D.T. 1966. Inflorescence initiation in the strawberry. Initiation in the field and its modification by post-harvest defoliation. Hort. Res. 6:33-44.

Moore, J.N. 1968. Effects of post-harvest defoliation on strawberry yield and fruit size. HortScience 3:45-46.

Moore, J.N., G.R. Brown, and E.D. Brown. 1970. Comparison of factors influencing fruit size in large fruited clones of strawberry. J. Amer. Soc. Hort. Sci. 95:827-831.

Olsen, J.L., L.W. Martin, P.J. Pelefske, P.J. Breen, and C.F. Forney. 1985. Functional growth analysis of the strawberry. J. Amer. Soc. Hort. Sci. 110:89-93.

Plakidas, A.G. 1964. Strawberry diseases. La. State Univ. Press. Baton Rouge.

Scott, D.H., A.D. Draper, J.K. McGrew, and I.C. Hunt. 1969. Resistance of strawberry varieties to leaf scorch diseases. Plant Dis. Rpt. 53:16-18.

Shaner, G. and R.E. Finney. 1977. The effect of nitrogen fertilizer on the expression of slow mildewing resistance in knox wheat. Phytopathology 67:1051-1056.

Strik, B.C. 1985. Flower bud initiation in strawberry cultivars. Fruit Var. J. 39:5-9.

Strik, B.C. and J.T.A. Proctor. 1988a. The importance of growth during flower bud differentiation to maximizing yield in strawberry genotypes. Fruit Var. J. 42:45-48.

Strik, B.C. and J.T.A. Proctor. 1988b. The relationship between achene number, achene density and berry fresh weight in strawberry. J. Amer. Soc. Hort. Sci. 113:620-623.

Webb, R.A., J.V. Purves, B.A. White, and R. Ellis. 1974. A critical path analysis of fruit production in strawberry. Scientia Hort. 2:175-184.

Wolf, A.F. 1926. Leaf scorch disease of strawberries. N.C. Agr. Sta. Tech. Bul. vol. 28.

Zheng and Sutton, 1994. Inoculum concentration, leaf age, wetness duration, and temperature in relation to infection of strawberry leaves by Diplocarpon earlianum. Can. J. Plant Pathol. 16:177-186. 